\author{
Ananyeva S.V. ${ }^{1}$, Khamrayev A.T. ${ }^{2}$, \\ ${ }^{1}$ Candidate of Science, A/Professor, Head of department of Analytics and Foreign Literary relations, \\ ${ }^{2}$ Doctor of Science, senior scientific researcher of M.O. Auezov Institute of Literature and Art, \\ Kazahstan, Almaty, e-mail: svananyeva@gmail.com, atilivaldi61@gmail.com
}

\title{
THE PHENOMEN \\ OF BICULTURAL AESTHETICS IN TRANSLATION (based on Kazakh and English poetry)
}

The article is devoted to the poetic analysis of the phenomenon of bicultural aesthetics based on poems of the prominent Kazakh poets, whose works have been translated into many world languages. Poetic heritage and translations of the poet serve as a factor of bicultural and simultaneously conjugative aesthetics. Translation analysis clearly shows that the creative writings of Kazakh poet is a bright example of not only lingual-cultural but also artistic and aesthetic interferentiality. This is a condition for simultaneous "destruction" of aesthetic integrity of the original and formation of a new one in the translation. We have outlined this phenomenon as conjugative one. This is a condition for simultaneous "destruction" of aesthetic integrity of the original and formation of a new one in the translation. We have outlined this phenomenon as conjugative one. Thanks to the introduction into the text of the translation of Kazakh words and symbols, foreign reader often gets first emotional information of communicative, evaluative, abstract synthesis, modal, explanatory nature at the unconscious level, in other words, it focuses on the fact that (identification of common relations with surrounding reality) is common for its perception, and is alien single (about specifics of national picture of the world or fragments (often visual: ornaments, yurts, whip, etc.), and only after that receives the implicit access to the world of content and form of artistic work.

Key words: bicultural aesthetics, conjugation, interferential, aesthetic tension.

Ананьева С.В. ${ }^{1}$, Хамраев А.Т. ${ }^{2}$,

М.О. Әуезов атындағы Әдебиет және өнер институтының аналитика және аударма қатынастар

${ }^{1}$ бөлімінің меңгерушісі, ф. ғ. к., Аоцент, ${ }^{2}$ бас ғылыми қызметкері, ф. ғ. А.,

Қазақстан, А^маты қ., е-mail: svananyeva@gmail.com, atilivaldi61@gmail.com

\section{Аудармадағы қосмәдениетті эстетикалық құбылыс (қазақ және ағымшын поэзиясының негізінде)}

Мақалада қазақтың көрнекті ақындарының шығармалары әлемнің көптеген тілдеріне аударылған өлеңдерінің мысалында эстетиканың поэтикалық құбылысына арналған. Ақынның поэтикалық мұрасы мен аудармалары ежелгі мәдениеттің және сонымен бірге конъюгативті эстетиканың факторы болып табылады. Аудармаларды та^дау қазақ мәтіндері тек ^ингвистикалық қана емес, сонымен бірге көркемдік және эстетикалық араласудың көрнекі үлгілері екенін айқын көрсетеді. Аудармаларда түпнұсқаның эстетикалық тұтастығын «бұзу» және оны бір уақытта жаңа көркем және эстетикалық бейнеге айналдыру бар. Біз бұл құбылысты конъюгативті деп белгілеАік. Қазақ ақындарының өлеңдерінің ағылшын тіліндегі аудармаларының өзара салыстырмалы талдауы аудармалардың тек мингвомәдени фактор ғана еместегін және олардың көркемэстетикалық өрнекке айналатынын айқын көрсетеді. Аудармадағы поэтикалық және эстетикалық заңдылықтарының «шиеленіс» өзара әрекеті - түпнұсқаның ерекше ұлттық эстетикалық тұтастығын «бұзады да» және аудармада объективті жаңа эстетикалық трансформацияға (өзгерістерге) апарады. Аудармалардағы бұл мәселені біз конъюгативті деп белгілейміз. Бұл құбылыс қазақ сөздері мен рәміздерінің ағылшын мәтініне аударылуы кезеңінде айқын көрінеді. Шет тілді оқырман көбінесе эмоционалды емес, коммуникативті, бағалау, дерексіз-жалпылама, модальдық, түсіндірме сипаттағы жаңа эстетикалық ақпаратты алады. О^ жаңа компоненттерді қабылдау үшін: ою-өрнектер, киіз үйлер, қамшы, арғымақ, және т.б.) көркем шығарманың мазмұны мен форма әлеміне кіруге дайын болады.

Түйін сөздер: мәдени эстетика, конъюгация, араласу, эстетикалық шиеленіс. 


\title{
Ананьева С.В. ${ }^{1}$, Хамраев А.Т. ${ }^{2}$, \\ ${ }^{1}$ К. ф. н. Аоцент, заведующий отделом аналитики и межлитературных связей, \\ ${ }^{2}$ А. ф. н. главный научный сотрудник Института митературы и искусства им. М.О. Ауэзова, Казахстан, г. Алматы, е-mail: svananyeva@gmail.com, atilivaldi61 @gmail.com \\ Феномен бикультурной эстетики в переводе (по мотивам казахской и ангмийской поэзии)
}

\begin{abstract}
Статья посвящена поэтическому феномену бикультурной эстетики, раскрываемому на примере анализа стихотворений видных казахских поэтов, произведения которых переведены на многие языки народов мира. Поэтическое наследие и переводы стихотворений выступают как фактор бикультурной и одновременно конъюгативной эстетики. Анализ переводов отчетливо показывает, что казахские тексты являются яркими образцами проявления в художественном тексте не только мингвокультурной, но и художественно-эстетической интерферентности. В переводах наблюдается "разрушение» эстетической целостности оригинала и одновременно его преобразование в новое художественно-эстетическое воплощение. Нами данный феномен обозначен как конъюгативный. Этот феномен отчетливо проявляется из-за внедрения в английский текст перевода казахских слов и символов. Реципиент обнаруживает, что в процессе воспроизводства иноязычного материала сталкиваются различные художественно-эстетические ценности и происходит противостояние и взаимовлияние сложных социокультурных Аискурсов, приводящих к появлению некой “срединной» маргинальной словесной бикультуры. Иноязычный читатель часто на имперсональном уровне получает эмоциональную информацию коммуникативного, оценочного, абстрактно-обобщающего, модального, объяснительного характера. Он сосредоточен на том, что его восприятие визуальных компонентов (орнамента, юрты, камчи, аргымака и т.А.) подготовит имплицитный доступ в мир содержания и формы художественного произведения.
\end{abstract}

Кмючевые слова: бикультурная эстетика, конъюгация, интерферентность, эстетическое напряжение.

\section{Introduction}

Modern Kazakh literature attracts the attention of the foreign reader mainly because it reflects, on the one hand, the socio-economic and cultural-political changes of the modern post-Soviet area, and on the other hand - the historical past of Kazakhstan, its present state and aspirations for the future. In the world, in connection with the destruction of the boundaries of the socio-religious, spiritual and cultural space, there is a surge of interest in learning, understanding and perception of the "alien" and rethinking of the national ethical, aesthetic and worldview systems. Under these conditions, the reception of the symbolic function of national artistic concepts repeatedly reinforces, which confirms the expansion of cooperation between Kazakhstan and the United States of America in culturalsphere. In a short period of time two anthologies "The Stories of the Great Steppe" have been published. First Edition (New-York Columbia University: Cognella Academic Publishing, 2013) and Summer Evening, Prairie Night, Land of Golden Wheat. The Outside World in Kazakh Literature. First Edition (NewYork Columbia University: Cognella Academic Publishing, 2015).

Translations of the works of Kazakh poets and writers into English appeared before foreign readers as a kind of cross-border artistic aesthetic unity, reproduced through the interaction of two discrete cultural systems. The recipient discovers that different artistic and aesthetic values encounter in the process of reproduction of the foreign language material and there occursa confrontation and interference of complex socio-cultural discourses that lead to the emergence of some "middle" marginal verbal biculture (the term by Qvortrup L). However, such "marginality" of the translation is a kind of bridge with the oncoming movement, where all the linguistic and structural-composition elements of the work intersect and intertwine in terms of discrete aspect. Therefore the recipient observes, for example, in the translation of poems by Kazakh poets into English language, the intense unity and struggle of poetic-structural opposites, which causes aesthetic opposition, representing a single conjugation and interfering character of the translation.

\section{Experiment}

Thus, the laws of aesthetic interference come into action and interaction. From this point of view, translations of works of Kazakh writers and poets into the English language are vivid example of the interpretation of such laws of literary 
cohesion. Taking into account this circumstance, in this article an attempt is made to explain the nature of perception of the Kazakh artistic word in the English language, where various forms of aesthetic interference are observed, which lead to a different interpretation of the text which has its own characteristics. It should be said, that the problem of artistic and aesthetic interference in science is deeply connected with psychology, linguistics, culture, thinking, etc. (Gibson, 1988; David H. Hubel \& Torsten N. Wiesel, 2005). Pervading all spheres of socio-political and cultural life of the society, it presents an ambiguous phenomenal character in literary criticism. This literary direction is extremely important for the determination of various interferential aesthetic phenomena and processes. The thing is that in the history of translation studies there were different points of view which were connected, one way or another, with the difficulties that arose during the translation process. Precisely these difficulties became the basis for interpreting the various worldviews of many scholars in the field of philology and researchers. Therefore, in literary criticism there were constant disputes about the "translatability" and "untranslatability" of the artistic work between the followers (Durishin, 1979), (Kopanev, 1972).The idea of "untranslatability" has always been relevant for the supporters of the idealistic approach, who believed that the world of artistic work cannot be objectively interpreted and transmitted by means of another language. However, this was an extremely univocal view of the translation process. It was based on the ideological principle of the objective unknowability of the universe and the whole essence of being. This approach was opposed to the works of the dialectical school of translation. At the center of the materialist approach there were representatives of the Czech tradition of translation, who were convinced that, basically, the reproduction of any artistic text and adequate implementation of the aesthetic principles of the original are possible. First of all, this was due to the materialist worldview on the cognition of the existence and the Marxist-Leninist approach to the translation process (Durishin, 1979).

Translations of the works of Kazakh poets into the English language, which are vivid examples of the manifestation of not only linguocultural, but also artistic and aesthetic interferences in the literary text, prove that it is a simultaneous "destruction" of the integrity of the original and the formation of a new aesthetic reality in translation. In this approach, there is no problem of "translatability" and "untranslatability" of the artistic work. The identification of deep correlation and genetic links between the conjugation form of the original and translation, the determination of the essential reasons for their modification, ultimately indicates "some simultaneous autonomy" of the translation from the original and from the tradition of the national translated poetic language, and avoids the extremity. So, the translation of the works of the Kazakh writers into the English language proves that it organically acts as a binary aesthetics and is a product of artistic interference. In fact, there is an intertextual interpenetration of two different texts, which, of course, gives a different aesthetic background. And this is clearly seen in the abovementioned anthologies published in America.

While working on the original, the translator of the anthologies has objectively faced many problems related to the adequate transfer of the original content and form: This led to the aesthetic tension, which resulted from the patterns of interference of different texts:

1. Interference due to the difference in the ideological concept of the original and the translation / religious-spiritual, socio-cultural, political and psychological, etc $/$.

2. Interference at the level of lexicon and symbol (words or sign of the original in translation, or author's words, which are absent in the original).

3. Interference due to the dissimilarity of the poetic systems. The interpreter, because of observance of the laws of the English verse, was forced to cast some meaningful elements of the original. Prosodic and formal categories of the Kazakh syllabic verse complicated the task, which resulted in a significant change in the artistic and aesthetic components of the original in translation.

4. Interference due to the difference in artistic means, contributing to the complication of the perception of figurative expressions. Expressive and pictorialmeans create a different aesthetic tension. Expressive means disappear completely in translation. Metaphor becomes a hard-to-reproduce means of poetics. In translation into English language, the political discourse that is present in the form of impersonal perception has intensified.

5. The whole concept of the symbolism of the original undoubtedly undergoes a serious interference change in the translation.

6. Repetitions (spatial parallelisms, verbal and sound) of structural and compositional elements originally act as aesthetic opposition in translation. 
7. Leveling the narrative, i.e. the change in the expression, tonality, rhythm, dynamics and spiritenergy of the original often and imperceptibly leads to the aesthetic indices, prevents the convergence of the translation to the original and reduces the level of their adequacy. G. Belger believes that preservation of the breath, intonation, size, rhythm and melody impedes the process of leveling the narrative (Belger G.K., 2011, 389).

It is impossible to investigate all the abovementioned problems of interference of the original and translation in one article. Therefore, this article discusses the issues related to the aesthetic tension at the level of vocabulary and the symbol of the original and translation, which arise because of interference between texts (Belger, 2011; Barannikova,1972).

\section{Results and discussion}

3.1 The hermeneutic aspect of translation of the realities of Kazakh culture and their perception by English - speaking readers

When reading "The Stories of the Great Steppe". First Edition (New-York Columbia University: Cognella Academic Publishing, 2013) and Summer Evening, Prairie Night, Land of Golden Wheat. The Outside World in Kazakh Literature. First Edition (New-York Columbia University: Cognella Academic Publishing, 2015), the recipient's attention will undoubtedly be focused on the cognition of the mysterious historical past of "Steppe». The artistic epithet "great" carries a hidden semantic function and anticipates the existence of the important historical information. The compilers of the anthologies aim at ensuring that English-speaking readers can penetrate deeper into the secrets of Kazakh life, thereby learning the diversity of the national world of the Kazakh people. The main thing is that behind this diversity there is a unified system of views, ways of expressing real and surreal codes that unite people. The works of Kazakh writers undoubtedly testify the high level of socio-cultural and artistic traditions of the Kazakh people, which continue to influence certain forms of the national worldview.

The vast expanses of the Kazakh land are a mysterious and unexplored territory for the English-speaking recipient, which significantly affects his/her attitude and perception of the world. The poetized image of the horse on the cover of the publication has a special cultural significance for both the batyr-nomad and the American cowboy. The most interesting is that the antithesis is aimed at leveling the zoo concept which assumes the with drawls of discreteness between symbolic images in the reader's perception. The authors emphasize the primordial relationship between human and nature (in this case Kazakh batyr - nomad and American cowboy), which is the same in different parts of the globe, and proceed primarily from a holistic understanding of the things and essences.

In the second anthology of Kazakh literature, "Summer evening, prairie night, land of golden wheat", like in the first, special attention is paid to the design of this book. The open doors of the yurt, from which one can see the expanse (sky, mountains, trees, etc.) - is a kind of symbolic invitation to the generous and beautiful world of the nomads. The anthology reveals "how the nomads of the Great Kazakh Steppe perceived the nature, and how this unique perception influenced on the writers and poets, is reflected in their work" (Ananieva S, 2015: 8).Undoubtedly, this circumstance has an important symbolic meaning and specifically emphasizes the national-aesthetic property of the reproduced material.

\subsection{Digital symbolism}

The sacred digital symbolism of the anthology "The Stories of the Great Steppe", which acts as a kind of interferential code in the aesthetic perception of the national world, attracts the attention. It includes seven prosaic texts and poems of seven poets. The figure seven in the nomad's consciousness means the integrity of the perception of the world and attitude, which unites the global horizontal and vertical structure of the nomads thinking. The horizontal line is the "four sides of the world", the signs of the earth and the sky ("shanyrak"), and the vertical are the three sides of the existence "heaven-father, Earth-mother and I (ego, spirit)". For a nomad, such a representation expresses, above all, spiritual harmony. The ancient nomad realized that his life was subject to the laws of the universe and sought to know its essence. Creating a discrete situation, the compilers of the Anthology want the reader to plunge into a completely different world where the national landscape is mixed with onomastic, toponymic notions that lead to the marginalization of time and space, including different epochs.

Seven contemporary Kazakh prose writers and seven poets are introduced to the American readers as one author (an auktor), the names of Kazakh writers and poets may be known or unknown to foreign readers. At a discursive level, they act as an abstract chief narrator, and in an actualizing form as an impersonal narrator (L. Kossuth, 2015). At 
first the foreign reader will perceive the Kazakh world not through the system of heroes and events, but through the prism of the national discourse. First and foremost, Kazakh writers in an auctorial sense convey the discourse of the natural, regular conditioning of human and nature, which is framed, first of all, by previously unknown artistic national ornamentation and speech characteristics (what they say and how they say, - A.H.).

Thus, the foreign reader often first at unconscious level receives emotional information of a communicative, evaluative, abstract-generalizing, and modal character. He is focused on identifying common links with the surrounding reality and the originality of the national picture of the world or fragments which are often visual: ornament, yurt, kamcha, etc. And only then he gets the implicit access to the world of content and form of the artistic work.

3.3 Notions-symbols, rhythmic-rhyme sand the "entry" of Kazakh words into the text in the foreign language.

A single author who symbolizes the integral connection of the creative authors - writers and poets, animates and reifies the national picture of the world, the steppe worldview through the refraction of the events and circumstances, an artistic conflict where the heroes and characters express the dominant objective and subjective idea. Using free imagination the recipient animates described events or specific episodes, symbols, portraits, speech of the characters. In the perception of a foreign reader, undoubtedly, the first stereotypes or stable signs, codes are being fixed in his mind in the form of a cliché. They are not only notions-symbols: steppe, argimak - horse, nomad, djailay - flocks, animals, dzhigit-a skilled, daring horseman, a young fellow, chaban - shephead, kamcha - whip and other onomastic and toponymic glossaries (Kazakh words in the English text functioning as etymological codes), but also ordinary words having analogies in the language to which the artistic text is being translated: batyr - brave warrior, hero, dastarkhan - a low table, meal, aryk - river, ata - father, apa mother, etc.

Thus, in the Anthology we observe an important artistic and aesthetic interference phenomenon: the "entry" of Kazakh words into the text in the foreign language. This affects the aesthetic awareness of the foreign recipients. The preservation of Kazakh words in the Anthology has different artistic functions. The reader can find an explanation of a complex, often untranslatable words, modal expressions and terms; They immerse the readers into a new, yet unknown, imaginative world. In some poetic translations, Kazakh words perform a rhythmic - rhyme function: "dress - aryqs" by Zhambyl, "auyls - days" by Abay, "qymyz - hands" by M. Zhumabayev, "steppestrains", "tulpars - daus" by S. Seifullin, "forest - steppe" by I. Zhansugurov, "light - steppe" by A. Sarsenbaev, "Taras - banks" by A. Tazhibayev, etc. Through such unusual artistic connections, the translator achieves complications in the logical and semantic categories of the work, where the abstract names and titles of real things make the reader's perception unusual, exotic. The translator at the sound level, "pushes" the words which havea linguistic difference, and achieves a thickening of the emotional-appraising perception of the text.

Sometimes a translator exacerbates the verbal and semantic disconnection of the poetic expression, based on contrasting opposition and associative figurative parallelism which result in a sense of hidden interconnection at the intertextual level. The interaction between such "native - alien" rhymes enables the appearance of the emotional state in the readers. In the anthology "Summer Evening, Prairie Night, Land of Golden Wheat", like in the first, a glossary that focuses on onomastic images (about one hundred new Kazakh words functioning as sign systems) plays a contextual role inthe perception of the original and performs a special artistic function in the text, simultaneously being realizedon the background of a narrow (microcontext) and a wide (macrocontext).

In the process of the artistic translation, a creative transformation of the text takes place. Translator S. Levshin is well acquainted with the national life of the Kazakh people. At the same time, the transcoding of the text with a significant number of lexemes which belong to a different culture and a different worldview is accompanied, sometimes, by the loss of sometimes of an essential, semantic part of the original.The glossary serves as a bridge between the picture of the world of the original and the picture of the world of the translation. Considering the lacunarity (skipping, inconsistency) of the constituent components of the original, the translator tries to keep the given form of the translated poem masterfully using Kazakh words with pronounced national and cultural specifics to impart a special artistic, cultural and aesthetic background in translation. Orientation to the initial meanings of the words and phrases has important meaning aimed to significantly expand the reader's artistic world. Immersing the reader in the unknown world, the translator hopes that he has information 
about the cultural life of the Kazakh people. Thus, Kazakh words in a figurative translation system simultaneously perform the function of a microcontext and a macro context, their interaction depends on the laws of aesthetic interference.

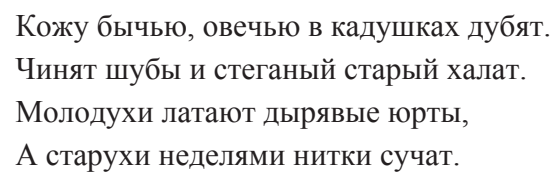

Sheep skin and ox hide are soaking in wooden casks, coats and quilted robes must be mended.

Young women are patching up holes in yurt shells, while their mothers spin thread for weeks on end.

Cranes are starting their southward march, passing over strings of caravans.

A melancholy silence fills the auyls-

where is the gay laughter of summer days?

The outlined Kazakh words in the English text at the micro-context level indicate only a specific national subject and phenomenon. But at the macrocontext level, these lexemes lead readers into the world of national poetry and national spirit, give the poly variance of aesthetic meanings and positions, figurative paradigms. For example, in the English text a word from the original has been entered: «in the auls", which stands in the anaphoric position and is used as a rhythmic-rhyme repetition in the structure of the verse. The same rhythmic function in this poem is performed by the word "yurt". Readers have a feeling of two-dimensionality, the possibility of correlating a binary / national and foreign / artistic space.

Some Kazakh lexemes emphasize the synonymic series, for example, in the poetic text along with the word "apa" the English word "mothers" is used. The correlation of such pairs provides a binary, not only synonymous, but also an antinomic system of symbolic codes of the native and foreign. So, the reader in the literary text sees one of the laws of parallelism. On the other hand, Kazakh words, entering into intertextual relations in the translated text, affect the foreign reader by an unusual, romantically national sound. He/she seesa different sound complex, which carries a certain aesthetic discrepancy in the worldview paradigm. The appearance of categorical "alien" verbal series in the translated text: astapuralla, attan, argamak, aqymaqi, etc., undoubtedly enhances certain interference difficulties between the recipient and the text. So, there is a tension between the text and the perception.However, not all comments to the "Glossary" in the Anthology can transmit an adequate content. For example, the Kazakh word astapuralla is explained as lord, have mercy, and the word apyrym-ay as exclamation of surprise of amazement. In principle, these words can perform the function of interjections and transmit the emotional exclamation of surprise and astonishment. In the first case, perhaps, the translators relied on the context of the work. Astapuralla, borrowed from the Arabic language, carries a deep religious content. It is formed from two words: astahpurallah and denotes "the recognition of sinfulness before Allah". The lexical component of the word apyrymay from the semantic point of view, which performs the etymological function in the "genotext" (Y. Kristev), is intensively used in the Kazakh society as the lexemes aqun, aghay, aruana, aynalayn, beshbarmaq, batur, bi and many others acting as hetereregenic codes in the memory of the Kazakh people. They perform the function of a single sustainable sign in translation, aimed at enhancing the "text perception effect" (R. Bart). For example, in the poem by M. Zhumabayev "Sasukkol, My Native Land" we can compare in the original and in the translation:

Птиц тут без счета, галдеж над округой повис.

Рыбы так много, что только лови, не ленись.

Бабы горластые здесь пересуды ведут,

Быстро меж тем белопенный взбивая кумыс.

\footnotetext{
The skies teem with birds, fist abound:

You can catch them with bare hands.

Women gossip and chatter for hours on end,

Whipping their frothy qymyz.
}

S. Seifullin in the poem "In Our Land" poetizes not only his native land, but also praises the people of labor:

Как тулпары, мы сильны,

Словно соколы, вольны,

Укрощать коней строптивых,

Все мы сызмальства должны! 
We are strong like tulpars,

like falcons free.

Each one of us learns in his earliest days

to tame a wild steed.

The introduction of numerous Kazakh words into the translated text is directly connected with the characterization of the national picture of the world, with the reflection of the determination of the national identity of the Kazakh people in a foreign audience. Kazakh words reveal the history, language, traditions, culture (as a holistic core in the depiction of the national picture by O. Spengler, A. Toynbee), religious beliefs, the specifics of the life style, landscape, etc.

\section{Conclusions}

Thus, Notions-symbols, rhythmic-rhymes and traditional Kazakh words (glosses) in translation reflect the fine connection of the picture of the world with national specifics, in particular, with the system of stereotypes in the cultural consciousness of the nomads. At the same time,
Kazakh words activate extensive perception in the process of understanding and reflecting on the national picture of the world, refracted in the verbal form of artistic comprehension of the existence, objectively contribute to the evolution of the artistic consciousness of a foreign reader. Undoubtedly, finally they lead to a change or evolution of the reader's individual worldview (Khalizev, 2009: 403). Moreover, in some translations we observe the language element as a factor that strengthens the author's poetic individuality. In general, the language element is conditioned by the specifics of national values that reveal the artistic world of the works.

The article may be of interest, first of all, for philologists and researchers of Kazakh literature, as well as specialists in the field of translation studies. It highlights theoretical issues of bicultural aesthetics on the example of the works of Kazakh authors, translated into English. The study of the features of translations of literary texts of Kazakh literature shows that the original work in foreign language naturally acts as a factor of bi-cultural and simultaneously conjugative aesthetics.

\section{Литература}

Богданов А.А. Тектология. Всеобщая организационная наука. В 2-х кн. Кн. 2 / Редколлегия Л.И. Абалкин (отв. ред) и др. - М.: Экономика, 1989. - 351 с.

Гибсон Д. Ж. Экологический подход к зрительному восприятию. - М.: Прогресс, 1988. - 465 с.

David H. Hubel and Torsten N.Wiesel. Brain and visual perception: the story of a 25-year collaboration. - Oxford University Press US, 2005. - P. 106.

Дюришин Д. Теория сравнительного изучения литературы. - М.: Прогресс, 1979. - 318 с.

Копанев П. И. Вопросы истории и теории художественного перевода. - Минск: изд. БГУ, 1972. - 295 с.

Бельгер Г.К. Энергия оригинала // Бельгер Г.К.. Избранные сочинения в 10-ти т. Т. 8. - Алматы: Балалар әдебиеті, 2011. $-480 \mathrm{c}$.

Ананьева С. Новая Антология казахской литературы в США // http://sozvuchie.by/news/2015-09-17

Хализев В.Е. Теория литературы: учебник для студ. высш. учеб. заведений. - 5-е изд., испр. и доп. - М.: Академия, 2009. $-432 \mathrm{c}$.

Кошут Л. Возвысить степь, не унижая горы // Мир Олжаса Сулейменова. Составители Машакова А.К., Калиаскарова А.Т. - Караганда, 2015. - 188 с.

Баранникова Л.И. Проблемы билингвизма и многоязычия. - М.: Наука, 1972. - С. 88-96.

\section{References}

Ananieva S. (2015) Novaya Antologiya kazakhskoy literatury v SSHA [New Anthology of Kazakh Literature in the USA]. ttp:// sozvuchie.by/news/-09-17 (in Russian)

Bogdanov A.A. (1989). Tektologiya. Vseobshchaya organizatsionnaya nauka [Tectual studies. Universal Organizational Science. In 2 books. Book. 2. Editorial Board Abalkin L.I. (ed., Ed.) and others]. Moscow: Economics, 351 p. (in Russian)

3. Barannikova L.I. (1972). Problemy bilingvizma i mnogoyazychiya [The essence of interference and specifics of its manifestation. Problems of bilingualism and multilingualism]. Moscow: Nauka. 88-96 p. (in Russian)

Belger G.K. (2011). Energiya originala. [Energy of the original. Belger G.K. Selected works in 10 volumes. T.8.]. Almaty: Balalar ədebieti, 480 p. (in Russian) 
Gibson J.(1988). Ekologicheskiy podkhod k zritel'nomu vospriyatiyu. [Ecological approach to visual perception]. M.: Progress, 465 p. (in Russian)

David H. Hubel and TorstenN.Wiesel (2005). Brain and visual perception: the story of a 25-year collaboration. Oxford University Press US, 106 p. (in Russian)

Durishin D. (1979). Teoriya sravnitel'nogo izucheniya literatury [The theory of comparative study of literature]. Moscow: Progress, 1979. 318 p. (in Russian)

Kopanev P.I. (1972). Voprosy istorii i teorii khudozhestvennogo perevoda [Issuesof history and theory of artistic translation]. Minsk: ed. BSU, 295 p. (in Russian)

Kossuth L. (2015). Vozvysit' step', ne unizhaya gory [Exalting the steppe, without degrading the mountains. World of Olzhas Suleimenov].Comp.: Mashakova A.K., Kaliaskarova A.T. Karaganda, 188 p. (in Russian)

Khalizev V. E. (2009). Teoriya literatury: uchebnik dlya stud. vyssh. ucheb. zavedeniy [ heory of Literature: a textbook for the university students. 5th ed., Rev. and add]. Moscow: Academy, 432 p. (in Russian) 